\title{
The Impact of Learning Content on Secondary Students' Motivation to Learn English in Lebanese Public Schools: Three Case Studies
}

\author{
Lama Komayha $^{1}$, Jihane Tarhini ${ }^{2}$ \\ ${ }^{1}$ Saint Joseph University of Beirut, P.O Box 17-5208, Lebanon \\ ${ }^{2}$ Saint Joseph University of Beirut, P.O Box 17-5208, Lebanon
}

\begin{tabular}{|c|c|}
\hline Artic & Abstract \\
\hline$\overline{\text { Artic }}$ & Purpose: The aim of this research is to investigate the effect of "the learning \\
\hline & content" on "students' motivation" in learning English as a foreign \\
\hline Revi & language. \\
\hline & $\begin{array}{l}\text { Approach/Methodology/Design: A mixed-method design was employed in } \\
\text { this study to explore the correlation between the two variables from the }\end{array}$ \\
\hline Кеуи & perspective of teachers and students. The sample included three secondary \\
\hline earning & public schools in the region of Mount Lebanon. Six classes were examined \\
\hline & each school. Qualitative data was obtained from the interview answers of \\
\hline & grade eleven English teachers and 18 one-session class observations in \\
\hline $\begin{array}{l}\text { Achievement, } \\
\text { English as a Foreign Language }\end{array}$ & $\begin{array}{l}\text { the three schools. Quantitative data was obtained from questionnaires of } \\
355 \text { grade eleven students in the three schools. }\end{array}$ \\
\hline (EFL) & $\begin{array}{l}\text { Findings: Interviews and observations' content analysis indicated that } \\
\text { students show a high level of motivation when they perceive the content as }\end{array}$ \\
\hline $\begin{array}{l}\text { Paper Type : } \\
\text { Research Article }\end{array}$ & $\begin{array}{l}\text { interesting, relevant, and beneficial. Surveys' SPSS analysis revealed the } \\
\text { existence of a strong positive significant correlation between the learning } \\
\text { content and students' motivation. }\end{array}$ \\
\hline Corresponding Author: & $\begin{array}{l}\text { Practical Implications: The study investigates the effect of one of the } \\
\text { repeatedly mentioned factors of students' motivation and demotivation in } \\
\text { learning English as a foreign language "the learning content". }\end{array}$ \\
\hline Lama Komayha & $\begin{array}{l}\text { Originality/value: It is recommended for teachers and educators to adjust } \\
\text { the learning content according to students' needs and interests in order to }\end{array}$ \\
\hline $\begin{array}{l}\text { Email: } \\
\text { Lama.Komayha@net.usj.edu.lb }\end{array}$ & $\begin{array}{l}\text { create chances of success and achievement for students, build students' } \\
\text { competence, relate students to their society, and allow technology } \\
\text { integration. }\end{array}$ \\
\hline
\end{tabular}

\section{Introduction}

Learning is a complicated process that requires the interaction of different aspects interchangeably such as the learner, the teacher, the learning environment, the learning content, the curriculum, the facilities, the society, the technology integration, the parents' involvement, and many others. However, researchers agreed that learners' motivation is a key element in learning, especially in learning a foreign language (Dornyei, 2007). Dornyei defined motivation as "the dynamically changing cumulative arousal in a person that initiates, directs, coordinates, amplifies, terminates, and evaluates the cognitive and motor processes whereby initial wishes and desires are selected, prioritized, operationalized and (successfully or unsuccessfully) acted out" (p.6).

Schunk et al. (2008) defined it as "the process whereby goal-directed activity is 
instigated and sustained" (p.4). While defining motivation, many researchers agree on the idea that motivated learners have a certain goal or desire that guides them to act out. Motivation is the reason for sustaining learning as well as initiating learning. Many students can start learning a foreign language because it may be an obligation in the educational system, but only a motivated learner will strive to acquire that language and overcome challenging obstacles.

In Lebanon, it is required from students to learn one foreign language besides Arabic: either English or French. Lebanese students start taking foreign languages classes from preschool till the secondary level (Bacha \& Bahous, 2011). Irie (2003) believed that there exists a motivation problem in learning English as a foreign language (EFL) because students are being exposed to the intended language only in the classroom. Other forms of communication are done in the country's native language which is Arabic. This is why EFL teachers in Lebanon are forced to exert extra efforts to build their students' competence and improve their achievement.

\section{Literature Review}

The concept of motivation has been examined deeply by researchers since the forties. However, many scholars could not agree on a single definition that explains it. Dornyie (2014) mentioned that researchers did not agree on the exact meaning of motivation. Gardner (1985) believed that language learning motivation refers "to the extent to which the individual works or strives to learn the language because of a desire to do so and the satisfaction experienced in this activity" (p. 10). Other researchers defined it differently, adding new components such as the interest, goal, desire, drive, willingness, attitude, locus of control. Another definition by Madrid (1999) sees motivation as "a set of processes which involve the arousal, direction and sustaining of behaviour" (p. 370). This implies that motivation cannot be seen as a product by itself; the accompanied behaviour is what reflects the motivational level. This definition also assures that motivation is not a single act; it is a process that needs to be sustained to yield desired goals.

Different perspectives probed the concept of motivation. According to behaviourists, external conditioning affects the occurrence of behaviours whether people were interested in it or not (Weiner, 2010). Behaviourists care about the observable behaviour and ignore the internal and invisible causes of the behaviour. More focus on internal processes started with cognitivism. Cognitivists cared to know the mental reasons for performing and engaging in learning tasks. Drive, instinct, need, desire were replaced by more cognitive concepts such as self- efficacy, learning helplessness, causal attribution, achievement needs, and locus of control. Another perspective that expounded the concept of motivation was the constructivism; "from the constructivist perspective, children do not learn through transmission of knowledge and information, nor are they motivated through extrinsic means such as reinforcements and rewards" (Chaile, 2008, p. 5). They are considered to hold full responsibility of their learning. Palmer (2007) mentioned that according to constructivists, 
"learners are responsible for the active creation and modification of knowledge as they strive to make sense of the world using background and previous experience" (p. 41).

Motivation is the major reason for succeeding in learning a language (Kaplan, 2012). Many questions revolve around Kaplan's statement: what motivates students and urges them to achieve? What affects the variance in the motivation level among students? What can teachers do to enhance their students' motivation? What effect does the type of students' motivation has on his/her achievement? How does the integrative/ instrumental or the intrinsic/extrinsic desires affect the sustaining of motivation? What factors influence language learners' motivation? What factors impede language learning motivation? These questions and many others are answered in a group of prominent language learning theories as follows:

\section{The Socio-Educational Model (1985):}

Many contemporary researchers based their studies on Gardner's socio-educational model. Gardner (1985) believed that the ingredients of motivation included the learners' efforts, desires, goals, and attitudes. He differentiated between two reasons for motivation: integrative and instrumental. A learner would be motivated for integrative reasons when s/he learns the language for its sake and not for an external objective. For example, when an EFL learner studies English because s/he loves it and desires to become a member in an Englishspeaking society, then this goes under the integrative category. On the other hand, the instrumental category includes external reasons for getting motivated. For instance, an instrumentally motivated EFL learner would study English because it is his/her gate to international job opportunities. Gardner et al. (2003) believed that students would acquire a language when they have "a goal to achieve, the desire to learn a language, and the motivation intensity to learn a foreign language". Although Gardner (1985) believed that integrative motivation is vital for language learning, he still could not ignore the importance of instrumental reasons as well such as the desire to please a teacher or get a work promotion.

\section{The Self-Determination Theory (SDT):}

SDT was suggested by Deci and Rayan (1985), and it named two different types of motivation than those of the socio-educational model: intrinsic motivation and extrinsic motivation. Intrinsic motivation is characterized by internal forces that urge a person to learn such as the need for achievement, and extrinsic motivation is related to external forces such as a grade or a bonus. Moreover, the researchers believed that motivation is achieved through the satisfaction of three basic needs: autonomy, competence, and relatedness. To reach or enhance motivation, learners should have responsibility over their learning, the feeling of capability to achieve, and a sense of belonging to the learning environment. Rayan et al. (2009) emphasized the significance of autonomy in being self-determining; "when autonomous, a person experiences his or her behaviour as self-organized and endorsed (Rayan et al., 2009, p. 115). On the other hand, Niemiec and Rayan (2009) mentioned that 
teachers' behaviours have a lot to do in either building students' autonomy or limiting it; "these behaviours exist along a bipolar continuum ranging from a highly controlling style on one end to a highly autonomy-supportive motivating style on the other" (p. 5)

\section{The Self-Efficacy Theory:}

Bandura (2004) believed that the way learners perceive their abilities affects their success in doing a job. People with a high self-efficacy believe that nothing could stop them "even if they face obstacles, they persevere and exert more effort to succeed. While those with a weak sense of efficacy may not even give it a try because they do not have any hope to succeed" (Komayha et al. 2018, p. 113). Because self-efficacy is a detriment of motivation according to Bandura (2004), it is believed that it can be enhanced by four ways: mastery experience, vicarious experience, verbal persuasion, and somatic and emotional state. So learners' selfefficacy and motivation would increase when they master a certain task, learn from others' successful experiences, get support from their environment, and maintain their somatic and emotional health.

Many researchers based their studies on these motivation theories and most of their results were aligned with them. Previous studies could be categorized in different ways: studies that focus on: motivational factors, demotivational factors, learners' motivation type, motivation enhancement methods, and the effect of the learning environment on students' motivation. To support the purpose of this article, we will mention some studies that aimed to explore students' motivational and demotivational factors.

Christophel and Gorham' study (1995): The purpose of this research was to explore students' demotives in EFL learning at the college level. Most of their findings were teacherrelated factors that caused demotivation from students' perspective. The two researchers mentioned them in their order of frequency: unsatisfactory assignments and grading system, boring and disorganized teachers, having no interest in the subject area, the lack of teaching material organization, and the unfair attitudes of teachers (Dornyei \& Ushioda, 2011).

Dornyei's study (1998): Dornyei cared about the reasons that demotivated students in foreign languages learning. In his data analysis, he relied on the first answers said by students because he wanted to distinguish between the causes of demotivation and the negative outcomes that accompany it. Results led to nine themes:

1. The teacher (personality, commitment, competence, teaching method).

2. Inadequate school facilities (group is too big or not the right level; frequent change of teachers).

3. Reduced self-confidence (experience of failure or lack of success).

4. Negative attitude towards the L2.

5. Compulsory nature of L2 study.

6. Interference of another foreign language being studied. 
7. Negative attitude towards L2 community.

8. Attitudes of group members.

9. Coursebook. (Dornyei and Ushioda, 2011, p. 163)

Kassem Shaaban and Ghazi Ghaith (2000): The purpose of this study was to investigate the motivation of university students who are taking intensive English classes in the American University of Beirut. Results showed the existence of a high positive correlation between learners' expectancy and their motivation. Moreover, there existed a negative correlation between the learners' proficiency and their effort to learn.

Heather D. Weger-Guntharp (2008): the researcher's main purpose here was to know what students exactly preferred out of all the activities and topics they deal with in class. Five themes emerged: "learning self-confidence, attitudes toward English language learning/community, personal English use, value of English learning, and international posture."As for the curriculum and the learning content, four dimensions arose: "grammarlexicon activities, personal media entertainment listening activities, reading-writing professional activities, and interactive listening-speaking activities." The researcher recommended designing class programs and curricula based on students' interests and preferences.

Rima Bahous, NahlaBacha, and Mona Nabhani (2011): The researchers' purpose was to explore the factors that impeded university students' EFL learning in Lebanon. The results analysis led to three main demotivating themes: "the excessive focus on writing skills, uninteresting materials, and unclear links between language courses and students' future careers. As the previously mentioned study, the researchers recommended taking students' interests and desires into consideration in planning curricula.

Espinar Redondo, R., \& Ortega Martin, J. L. (2015): The purpose of this research was to identify the factors of secondary students' motivation in EFL learning. Results showed that "the teacher, the four skills (reading, writing, listening, speaking), students' interests, and daily habits" were the main factors that affected students' motivation. It was recommended for teachers to use cooperative learning strategies in teaching to increase the level of their students' motivation.

As we notice in the previous studies, some motivational and demotivational factors were recurrent in different contexts. One of these factors is the learning content which seemed to either motivate or demotivate students to learn EFL. Other researchers and studies also considered the learning content a major factor of students' motivation or demotivation. Here are some of them: 
Aliakbari\&Hemmatizad (2015)

Ghadirzadeh et al. (2013)

Hamada and Grafstorm (2012)

Amemori (2012)

Bahous et al. (2011)

Hirvonen (2010)

Falout, Elwood, and Hood (2009)

Sakai and Kikuchi (2009)

Muhonen (2004)

Dornyei (1998)

Christophel and Gorham (1995)

Source: Authors

Table 1 shows that learning content-related factors have been considered a demotivating factor since 1995. Besides, the studies mentioned in the table indicate that this variable have been demotivating in different times, regions, contexts, and grade levels. Literature and previous research assure that many factors affect students' motivation. In this study, we shed light on one of them: the learning content.

\section{Methodology and Procedures}

The purpose of this study was to investigate the effect of the learning content on students' motivation learning English as a foreign language. Specifically, we aim to answer the following research question: To what extent does the learning content affect the motivation level in EFL learning for grade eleven students in public schools?

\section{Context of the Study}

In Lebanon, there are four types of schools: private schools, semi-private schools, public schools, and UNRWA schools. The school journey includes three years in the preschool level, six years in the elementary level, three years in the intermediate level, and three years in the secondary level. The Lebanese educational system requires students to pass the unified official exams conducted at the end of the intermediate level (Brevet) and the secondary level (Baccalaureate II). This allows them to be upgraded to secondary level or the university level. According to the Center of Research and Development (2018), 30.7\% of the Lebanese students are enrolled in public schools. Although public schools are financed by the Ministry of Education and Higher Education (MEHE) and reflect the vision of the Lebanese government, the majority of the Lebanese students are still enrolled in private schools (52.7\%). There are many well-known reasons for this preference such as providing better facilities, more supervision, and better quality of education (Mattar, 2010).

\section{Method}


The study followed the mixed-method design, quantitative qualitative model. According to Creswell (2012), mixed methods research is an approach to inquiry involving collecting both quantitative and qualitative data. The core assumption of this form of inquiry is that the combination of qualitative and quantitative approaches provides a more complete understanding of a research problem than either approach alone. (p. 37).

Regarding the quantitative parts, 355 students completed a questionnaire which focuses on the link and the effect of the independent variable (learning content) on the dependent variable (students' motivation). For the qualitative part, a 10 to 15 minute interview was conducted with each of the 18 grade eleven teachers, and one-session observation took place in 18 grade eleven classes to notice the participation level of students when the content is different.

\section{Sample and Instruments}

The sample was purposefully chosen, and it comprised three secondary public schools in the region of Mount Lebanon. School G has 530 students divided into 26 sections of grades ten, eleven, and twelve. School M has 436 students divided into 20 sections. School B has 523 students divided into 25 sections. The sample consisted of six grade eleven students from each school. The total number of participants was 355 students.

The instruments of this study included an interview conducted with 18 grade eleven teachers to explore their perspective about the effect of the learning content on students' motivation, a questionnaire completed by 355 students to investigate their perception about the learning content and find its effect on their motivation, and an observation checklist which was filled during/after eighteen grade eleven class visits to observe the participation level of students with different learning contents. The three instruments were researchers-made and were tested for validity and reliability.

\section{Results and Discussion}

\section{Interview Findings}

A major interview question was about the reasons that let students show a high level of motivation throughout a period. $66 \%$ of the teachers mentioned that the learning content was a major reason. For example, T4 in SG said: "It depends on the topic and the way of introducing it. When the topic is interesting, they show higher motivation." T5 in SG said: "The topic, whether the lesson is easy or difficult, using technology, discussions, debates...all these motivate students." T2 in SM said, "My students get really motivated when I relate the topic to their everyday life." T4 in SM said: "When there is a topic that tackles their interest, where they try to convince each other with their point of view." T6 in SM answered: "When we speak about their families, love, dreams... and when they try to express their ideas." $\mathrm{T} 1$ in SB also said: "If the lesson is interesting to them, the topic is related to their real life, they 
have information about the topic, and they have seen movies about related topics... 'T5 and T6 in SB believed that students feel enthusiastic to participate in discussions related to topics they are familiar with such as love, sports, politics, movies, friendship.

\section{Survey Findings}

Table 2: Learning Content Mean

\begin{tabular}{lrrrrr}
\hline & $\mathrm{N}$ & Minimum & Maximum & Mean & $\begin{array}{c}\text { Std. } \\
\text { Deviation }\end{array}$ \\
& 355 & 1 & 5 & 2.83 & 1.258 \\
$\begin{array}{l}\text { I am interested by grammar lessons } \\
\begin{array}{l}\text { English topics are similar to the official } \\
\text { exam topics. }\end{array}\end{array}$ & 355 & 1 & 5 & 3.42 & 1.121 \\
$\begin{array}{l}\text { I have to memorize vocabulary words to } \\
\text { be up to the class level. }\end{array}$ & 355 & 1 & 5 & 3.33 & 1.334 \\
$\begin{array}{l}\text { The topics of the English book are } \\
\text { interesting. }\end{array}$ & 355 & 1 & 5 & 3.21 & 1.137 \\
$\begin{array}{l}\text { I am interested in reading long English } \\
\text { passages. }\end{array}$ & 355 & 1 & 5 & 2.78 & 1.326 \\
$\begin{array}{l}\text { I participate in class when the content is } \\
\text { exciting }\end{array}$ & 355 & 1 & 5 & 3.71 & 1.237 \\
\hline
\end{tabular}

Source: Authors

Table 2 shows that students participate the most when they perceive the content as exciting (highest mean $=3.71$ ). The second highest mean was related to the resemblance between their book topics and those of the English official exam. The table also shows that students neither very interested in reading long reading passages (mean $=2.78)$ nor in taking grammar lessons $($ mean $=2.83)$

\section{The Effect of Learning Content on Students' Motivation:}

In order to find the effect of the learning content (independent variable) on students' motivation (dependent variable), we used the simple linear regression. "Simple linear regression is used to describe data and to explain the relationship between one dependent variable and one independent variable" (Solutions, S., 2016, p.18). Gay (2012, p. 213) mentioned that a "simple linear regression equation, is a prediction equation including two variables that individually predict a criterion, resulting in a more accurate prediction".

Table 3: Learning Content and Students' Motivation

\begin{tabular}{|c|c|c|c|}
\hline & Mean & Std. Deviation & $\mathrm{N}$ \\
\hline motivation average & 3.4326 & 0.73317 & 355 \\
\hline Learning Content average & 3.2136 & 0.73752 & 355 \\
\hline
\end{tabular}




\begin{tabular}{llrr} 
& & motivation_average & Learning_Content_average \\
Pearson & motivation_average & 1.000 & 0.631 \\
Correlation & Learning_Content_average & 0.631 & 1.000 \\
Sig. (1- & motivation average & & 0.000 \\
tailed) & Learning_Content_average & 0.000 & \\
$\mathrm{~N}$ & motivation average & 355 & 355 \\
& Learning_Content_average & 355 & 355 \\
\hline
\end{tabular}

\section{Source: Authors}

The $\mathrm{P}$ value in the correlation table $=0.000<0.05$. This indicates a significant correlation between the Learning Content (independent variable) and Students' Motivation (dependent variable).

Table 5: Model Summary: Learning Content \& Students' Motivation

\begin{tabular}{lrrrr} 
& & & Adjusted R & Std. Error of the \\
Model & $\mathrm{R}$ & R Square & Square & Estimate \\
1 & $.631^{\mathrm{a}}$ & 0.398 & 0.397 & 0.56953 \\
\hline
\end{tabular}

Source: Authors

The $R$ and $R^{2}$ values are presented in table 5. The $R$ value represents the simple correlation = 0.631 , which indicates a high degree of correlation. This means that there is a strong significant positive correlation between the Learning Content and Students' Motivation. The $R^{2}$ value indicates how much of the total variation in the dependent variable, can be explained by the independent variable. In this case, $39.8 \%$ are close to the fitted regression line.

Table 6: ANOVA: Learning Content \& Students' Motivation

\begin{tabular}{|c|c|c|c|c|c|}
\hline Model & Sum of Squares & Df & $\begin{array}{l}\text { Mean } \\
\text { Square }\end{array}$ & $\mathrm{F}$ & Sig \\
\hline 1 Regression & 75.788 & 1 & 75.788 & 233.650 & $.000^{\mathrm{b}}$ \\
\hline Residual & 114.502 & 353 & 0.324 & & \\
\hline Total & 190.290 & 354 & & & \\
\hline
\end{tabular}

Source: Authors

This ANOVA table tells how well the regression equation fits the data and predicts the independent variable. Because the $\mathrm{P}$ value is $0.000<0.05$, we can say that there is a statistical significance in the regression model describing the effect of learning content on motivation. 


\begin{tabular}{|c|c|c|c|c|c|c|c|}
\hline \multirow[b]{3}{*}{ Model } & \multicolumn{2}{|c|}{$\begin{array}{l}\text { Unstandardized } \\
\text { Coefficients }\end{array}$} & \multirow[t]{2}{*}{$\begin{array}{l}\text { Standardized } \\
\text { Coefficients }\end{array}$} & & & $\begin{array}{r}95 . \\
\text { Confi } \\
\text { Interva }\end{array}$ & $\begin{array}{l}\% \\
\text { lence } \\
\text { for B }\end{array}$ \\
\hline & & Std. & & & & Lower & Upper \\
\hline & B & Error & Beta & $\mathrm{T}$ & Sig. & Bound & Bound \\
\hline 1 (Constant) & 1.416 & 0.135 & & 10.468 & 0.000 & 1.150 & 1.683 \\
\hline Learning_Content_average & 0.627 & 0.041 & 0.631 & 15.286 & 0.000 & 0.547 & 0.708 \\
\hline
\end{tabular}

Source: Authors

The Coefficients table provides us with the necessary information to predict motivation from learning content, as well as determine whether the learning content contributes statistically significantly to the model. We notice that $\mathrm{P}=0.000<0.05$ so there is a significant effect of learning content on motivation. The unstandardized coefficient $=0.627$. This means that when the learning content increases by one unit, the motivation increases by 0.627 .

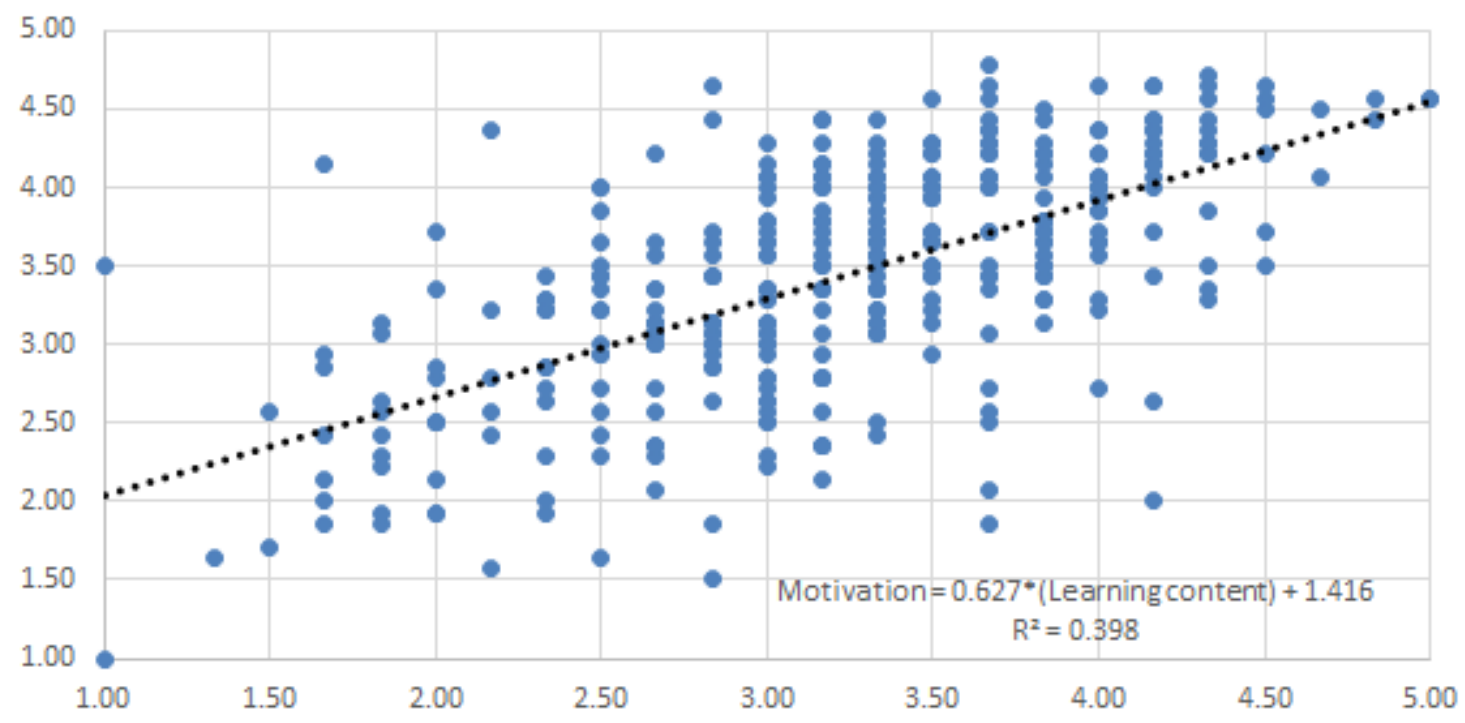

Figure 1: Coefficients, Learning Content and Motivation

In the Lebanese public schools, the curriculum is set by the Ministry of Education, thus all the public schools give the same content to their students. For this reason, during our observations, some teachers in different classes were explaining the same content, however the participation level varied. Here is a summary of the findings:

Table 8: Learning Content \& Students' Participation

\begin{tabular}{lll}
\hline School G & Learning Content & Students' Participation \\
Class 1 & Generation Gap & High \\
Class 2 & Generation Gap & Low \\
\hline
\end{tabular}




\begin{tabular}{lll}
\hline Class 3 & Family Relations & High \\
Class 4 & Family Relations & Moderate \\
Class 5 & How to write a body paragraph & Low \\
Class 6 & Subject-Verb Agreement & Low \\
School M & Learning Content & Students' Participation \\
Class 1 & Environment & Low \\
Class 2 & Depression & High \\
Class 3 & Environment & Moderate \\
Class 4 & Depression & High \\
Class 5 & Plastic Surgery & High \\
Class 6 & Essay Writing (Technology) & Low \\
School B & Learning Content & Students' Participation \\
Class 1 & Modern Slavery & Low \\
Class 2 & Generation Gap & High \\
Class 3 & Modern Slavery & Low \\
Class 4 & Environment & Low \\
Class 5 & How to write a conclusion (Pollution) & Low \\
Class 6 & Essay Writing (Pollution) & Low \\
\hline
\end{tabular}

Source: Authors

Out of the eighteen grade eleven classes, six showed a high level of participation. The topics discussed in these classes were: generation gap, family relations, depression, and plastic surgery. In class 1 School G, students were profoundly sharing their experiences with their teacher and friends regarding the character similarities and differences they have with their parents. In classes $2 \& 5$ in School G, most students were passive and they did not exert any effort to participate. In class 3 School G, the topic seemed to be touching to girls. They were asked to choose one dear person among their parents and speak about him/her. Girls spoke enthusiastically about their mothers, fathers, or siblings. Some of them were emotional and they were nearly crying while describing a family member.

The scene was different in some classes of School M. The discussed topic in classes 1 and 3 was the same. It tackled the subject of environment which seemed to be uninteresting to students. Another uninteresting topic was writing a body paragraph. This was evident in class 6 where students sat quietly and passively listening to the teacher's explanation. However, this was not the case in classes 2 and 4. The topic "depression" intrigued the students" curiosity to listen to the teacher's explanation and share in return the information they had about the topic. Many of them had stories about depressed people they knew. As for class 5, the topic was "plastic surgery". Here, the participation style depended on different genders. For example, girls were more knowledgeable about the topic, and boys as well were attentively listening to girls' information and reflections.

As for School B. the majority of classes showed a low level of motivation. One class out of six showed a high level of motivation. The discussed topic was "generation gap". Students 
compared their lifestyle nowadays with their parents' in the past. They also spoke about the causes of their major and minor arguments with their parents. Peers tried to evaluate the reasons of the generation gap and choose who to blame. Students in other classes seemed to be demotivated in discussing the topics of modern slavery, environment, and essay writing.

\section{Discussion}

The triangulation of the three instruments gave us a comprehensive idea about the effect of the learning content on students' motivation. Gay (2012, p. 632) identified triangulation as "The use of multiple methods, data collection strategies, and data sources to get a more complete picture of what is being studied and to crosscheck information".

Regarding the interview answers, most teachers linked the learning content to students' motivation level. They mentioned that when students perceive the content as interesting, they would be more enthusiastic to participate. On the other hand, students would be passive to participate when the content seems to be boring and irrelevant. This gets in line with the findings of Muhonen (2004), Hirvonen (2010), Dornyei \& Ushioda (2011), and Amemori (2012). They attributed secondary students' demotivation to the learning content. However, the content was not the only cause of students' demotivation. For example, some classes in this research were discussing the same topic, yet they did not show the same level of participation. This designates that the learning content should be accompanied with suitable teaching practices to increase students' motivation. The survey findings also indicated the existence of a strong positive significant correlation between the two variables. This shows that students themselves know that they tend to get more involved in the session when the topic interests them. Teachers as well assured what students believed when they agreed that they witnessed a high level of motivation when the content was appealing to students. Dornyei \& Ushioda (2011) mentioned that even if the learning content was not interesting to students, it could still be motivating if students knew its benefits. Teachers should explain the added value of learning content to the students' educational life. Teachers can link the learning content benefit to different aspects such as personal goals, social goals, and future goals. Brophy (2005) believes that a "relevant content or task succeeds in grasping the attention of students, and satisfies their needs for power, achievement, and affiliation" ( $p$. 169).

In our observations, we noticed that all students showed passivity in writing sessions. Students seemed to feel demotivated when they were supposed to write a paragraph or an essay. Tarnopolsky (2000) mentioned that students do not prefer writing tasks because they either lack writing abilities or they are not writing about an interesting prompt. Taking the findings of the three instruments into consideration, we can say that the learning content affected students' motivation differently.

Williams \& Williams (2011) advised teachers to plan and design the learning content taking the following objectives in consideration: 
1. Increasing students' chances of success and achievement: this objective is related to the content difficulty level. It should not be higher that the students' level because this will lead to repeated failures. Moreover, it should not be lower than the students' level because this will cause boredom. The level should be achievable; it should create the students' experience of success and this in return will enhance their self-efficacy (Bandura, 2004). Creating the experience of success could be supported by the implementation of differentiated instructions in the class. Rasheed\& Wahid (2018) defined differentiation as "the teachers' responses to the learners' needs which may differ from learner to learner" (p. 194).

2. Forming students' ownership: when teachers give students the chance to choose what to learn, students grow a sense of ownership over their learning. Rayan et al. (2009) mentioned that guiding students to be autonomous learners increase their intrinsic motivation and achievement as well. Although we previously mentioned that the topics are already assigned by the government in the Lebanese public schools, teachers still have control over the learning activities and the classroom tasks.

3. Building students' competency: teachers should not only present new information to students, but they should also guide them to analyze information, think critically, do projects, do field studies, synthesize and evaluate opinions, and change theories into real life experiences. Although Williams \& Williams (2011) suggested earlier that the content should be achievable, they also believe that it should be challenging to ameliorate students' motivation.

4. Relating students to their society: teachers assured that students enjoyed talking about issues that are relevant to their society, families, and lives. They like to share their opinions with their friends especially if the topic is familiar to them. Legg ad Wilson (2009) mentioned that the learning content should be derived from the students' environment to guarantee their motivation.

5. Integrating technology: In our class visits, we rarely observed the use of technology although some classes were equipped with LCD projectors. Manzo (2010) spoke about the importance of using technology in teaching in this era. This generation is used to technology and knows exactly how to take advantage of it. Teachers should consider it a privilege and integrate it in their weekly lesson presentations. It is also recommended for the Lebanese government to equip all public schools with the necessary tools to use technology in the teaching and learning process.

\section{Conclusion and Suggestion}

Our study investigated the effect of one of the repeatedly mentioned factors of students' motivation and demotivation in learning English as a foreign language "the learning content". The interview, survey, and observation findings revealed that the learning content has a strong effect on students' motivation. Students participate enthusiastically ad seem to enjoy 
the period when the content is interesting, appealing, relevant, and beneficial. It is recommended for teachers to explore the topics that arouse their students' interests, and design their learning content in a way that increases students' chance of success and achievement, forms students' ownership, build students' competence, relate students to their society, and allow technology integration.

\section{Conflict of Interest}

The authors of the article declare no conflict of interest.

\section{Funding}

This research study was not funded by any institution. The authors conducted the study on their own expenses.

\section{References}

Aliakbari, M., \&Hemmatizad, M. (2015).On students' de-motivation, gender, major, and educational level in Iranian EFL context. English Language Teaching, 8(4), 106116. Retrieved from http://search.proquest.com/docview/1773220764?accountid=8555

Amemori, M. (2012).Demotivation to Learn English among University Students in Finland. University of Jyvaskyla, Finland.

Bahous, R., Bacha, N., \&Nabhani, M. (2011).Motivating Students in the EFL classroom: A Case Study with Perspectives.Center of Science and Education, 4(3), 33-43.

Bacha, N., \& Bahous, R. (2011). Foreign Language Education in Lebanon. Journal of Language Teaching and Research, Vol. 2, No. 6, pp. 1320-1328

Bandura, A. (2004). Swimming against the mainstream: The early years from chilly tributary to transformative mainstream.Behavior Therapy, 42, 613-630.

Brophy, J. E. (2005). Goal theorists should move on from performance goals. Educational Psychologist , 40 , 167 - 176. doi:10.1207/s15326985ep4003_3

Center of Research and Development in Lebanon (2018), retrieved from www. CRDP. Org

Christophel, D. M., \& Gorham, J. (1995).A test-retest analysis of student motivation, teacher immediacy, and perceived sources of motivation and demotivation in college classes. Communication education, 44(4), 292-306.

Creswell, J. W. (2012). Research design: Quantitative, qualitative, and mixed methods approach (2nd edition.). Thousands Oaks, CA: Sage, 270-290.

Deci, E. L. \&Rayan, R. M. (1985).Intrinsic motivation and self-determination in human behaviour. New York: Plenum.

Dörnyei, Z. (1998). Motivation in second and foreign language learning. Language teaching, 31(3), 117-135.

Dornyei, Z. (2007). Research methods in applied linguistics: Quantitative, qualitative, and mixed methodologies (pp. 95-123). Oxford: Oxford University Press. 
Dornyei, Z. (2014). The psychology of the language learner: Individual differences in second language acquisition. Routledge.

Dörnyei, Z. and E. Ushioda (2011).Teaching and researching motivation. Harlow: Pearson Education.

EspinarRedond, R., \& Ortega Martín, J. L. (2015). Motivation: The road to successful learning. Issues in Teachers' Professional Development, 17(2), 125-136.

Falout, J., Elwood, J., \& Hood, M. (2009). Demotivation: Affective states and learning outcomes. System, 37(3), 403-417.

Gardner, R. C. (1985). Social psychology and second language learning: The role of attitudes and motivation. London: Edward Arnold.

Gardner, Robert C. and A-M.Masgoret (2003). Attitudes, motivation and second language learning: a meta-analysis of studies conducted by Gardner and associates. Language learning, 53(S1), 167-210.

Gay, L. R. (2012). Educational research: competencies for analysis and applications $\left(10^{\text {th }}\right.$ edition). United States of America. Pearson Education

Ghadirzadeh, R., PourabolfatheHashtroudi, F., Shokri, O. (2013).Study of the Effective Factors on the University Students' Underachievement in English Language Learning.English Language Teaching, 11(6), 122-129.

Hamada, Y. and Grafstorm, B., (2012). Demotivating Factors in Learning Japanese as a Foreign Language. Akita University.

Hirvonen, M. (2010).Demotivation in learning English among immigrant pupils in the ninth grade of comprehensive school (Master's thesis). Retrieved from https://jyx.jyu.fi/dspace/handle/123456789/22990 on 08/09/2012.

Irie, K. 2003. What do we know about the language learning motivation of university students in Japan?.JALT Journal, 25(1), 86-100.

Kaplan, A., Katz, I., \&Flum, H. (2012). Motivation theory in educational practice: Knowledge claims, challenges, and future directions. APA educational psychology handbook, 2, 165-194.

Komayha, L., Moukarzel, D., \&Daccache, S. (2018). Teachers' Perceptions of Secondary Students' Motivation to Learn English in Lebanese Public Schools: Two Case Studies. International Journal of Education and Research, 6(7),111-120.

Mattar, D. M. (2012).Factors affecting the performance of public schools in Lebanon. International Journal of Educational Development, 32(2), 252-263.

Muhonen, J. (2004). Second Language Demotivation: Factors That Discourage Pupils from Learning the English Language. University of Jyvaskyla.

Niemiec C. \&Rayan R. (2009).Autonomy, competence, and relatedness in the classroom: Applying self-determination theory to educational practice. University of Koshester, New York. Retrieved from: www.sagepublications.com

Palmer, D. (2007). What Is the Best Way to Motivate Students in Science? Teaching ScienceThe Journal of the Australian Science Teachers Association, 53(1), 38-42.

Rayan, R., Williams, G., Patrick, H., and Deci, E. (2009). Self- Determination Theory and Physical Activity: The Dynamics of Motivation in Development and Wellness. Helleic Journal of Psychology, 6, 107- 124. 
Sakai, H. \& Kikuchi, K. (2009). Japanese Learners’ Demotivation to Study English: A Survey Study. JALT Journal, 31(2), 183-204.

Shaaban, K. \&Gaith, G. (2000).Student Motivation to Learn English as a Foreign Language. Foreign Language Annals, 33(6), 632-644.

Schunk, D. H., Pintrich, P. R., \&Meece, J. L. (2008).Motivation in education: Theory, research, and applications. Prentice Hall.

Solutions, S. (2016). Statistics solutions: Advancement through clarity. Retrieved from http:// www.statisticssolutions.com/theoretical-framework.

Tarnopolsky, O. (2000). Writing English as a foreign language: A report from Ukraine.Journal of Second Language Writing, 9(3), 209-226.

Weger-Guntharp, H. (2008). Learner Motivation and Preferences: Realities in the Language Classroom. Georgetown University.

Weiner, B. (2010) . The development of an attribution based theory of motivation: A history of ideas. Educational Psychologist, 45 ,28 - 36. doi:10.1080/00461520903433596 